\title{
Reino de Deus, experiência que aponta para a vida Um estudo da experiência portadora de vida a partir da obra "Jesus Cristo Libertador: ensaio de cristologia crítica para o nosso tempo", em Leonardo Boff
}

\author{
Orientador: Jenura Clothilde Boff \\ Mestrando: Rita de Cássia Rosada Lemos \\ Área de Concentração: Teologia Sistemático-Pastoral \\ Linha de Pesquisa: Religião e Modernidade
}

No anúncio do Reino de Deus, Jesus evocava a tradição viva de uma experiência de Deus atuante na história. A chegada do Reino é simultânea à chegada de Jesus. Ele é o próprio Reino em atos. Em sua palavra e ação, mostram-nos os Evangelhos, Deus reina no mundo como aquele que dá a vida. A nossa pesquisa apresenta o que vem a ser Reino de Deus na Sagrada Escritura e na sociedade contemporânea. Reafirma sua centralidade em Jesus como acontecimento, já, na história, e em construção, Reino ainda não plenamente realizado. Este estudo se torna fundamental para atingirmos nosso objetivo de trazer presente a teologia de Leonardo Boff, a partir da obra: Jesus Cristo Libertador, como contribuição para a experiência de sentido da vida, provinda do Reino de Deus. Inseridos no contexto da América Latina, constatamos que o foco emergente em nosso continente é a vida do ser humano. É urgente assumir a tarefa de erguer e humanizar a vida. Percebemos, pela cristologia de Boff, que o Reino de Deus é o nome que expressa à experiência de Jesus, é o objetivo de sua libertação, é a Boa Notícia da vida em plenitude. Nesta obra, ele destaca que o Reino é realização de Deus, para esta história, realização que aponta para a vida eterna. Estudar a pessoa de Jesus provoca, em nós, sermos envolvidos em sua realidade, e percebermos nele um ser humano contextualizado como outros. No entanto, na orientação que Jesus dava à sua vida emergiu o próprio Deus e a verdade do ser humano. O Reino de Deus transparece, então, como experiência de plenitude da vida.

Palavras-chave: Leonardo Boff; Reino de Deus; libertação; Vida Escatológica 